\title{
Aerobics Gymnastic, Fitness, Anxiety, Academic Grades of Health Diploma Students from Remote Area in Indonesia
}

\author{
Lucky Herawati $^{1}$, Agussalim $^{2}$, Maryana $^{3}$, Suharyono $^{4}$ \\ ${ }^{1}$ Jurusan Kesehatan Lingkungan, Politeknik Kesehatan Kemenkes Yogyakarta \\ ${ }^{2}$ Jurusan Keperawatan, Politeknik Kesehatan Kemenkes Jayapura \\ ${ }^{3}$ Jurusan Keperawatan, Polteknik Kesehatan Kemenkes Yogyakarta \\ ${ }^{4}$ Jurusan Keperawatan Gigi, Politeknik Kesehatan Kemenkes Yogyakarta
}

\begin{abstract}
Grade of academic student achievement of Diploma Students from remote area of Indonesia showed under standard of academic evaluation which was lower than 2.75. The standard of education has been published by the Ministry of Education of Indonesian Republic as part of educational system inside the country. Purpose of this study was to measure the effect of aerobic gymnastic to the wealth fitness, anxiety, and grade result of students from remote area. Method of this study used experimental study by pretest and post test by group control design. Sample of this study was 79 students from the North of Kalimantan which was 39 students were as group intervention and 40 students were as group control. The intervention was aerobic gymnastic which conducted 5 times a week every morning for 4 weeks. Data analysed by Mancova with specific gender, age and parental education. Result of this study shown that $p_{V}<0,05$ meaning to say was an effective correlation between aerobic gymnastic to the wealth fitnes, anxiety, and grade of students from remote area. Recomendation of this study that educational system in Indonesia can use aerobic gymnastic in order to increase wealth fitnesses, academic grade, and decrease of student anxiety.
\end{abstract}

Keywords: Aerobic Gymnastic, Fitness, Anxiety, Academic grade

\section{Background}

In 2013, Polytechnic of Health of Yogyakarta have received 105 newly students with classes partnership with recidency "M" which is a remote area in the boundary between Nort of kalimantan and Sabah Malaysia. Students have been distributed at five departments inside of Politeknik Kesehatan Kemenkes Yogyakarta. At the first semester in 2013, the result of their study shown a pity ability in academic progressivity. Based on evaluation data from the first semester of another department shown that there was no students passed from two subjets. Management of the Polytechnic of Health of Yogyakarta was so worrying of this phenomena especially retake the subjects was never improve their capability. This was based on their experiences around 2009-2012 with students from regency "B" West Kalimantan Province, and regency "SS" from West Papua.

This condition must have more attention refers to accreditation result of Polytechnic of Health of Yogyakarta based on Alumni Indeks Cumulatif Prestation, passing rate is not timely, and increasing their studying budget from their local government. On the other hand, that this program was a priority of the Ministry of Health of Indonesian Republic in order to fulfill health practitioners need of remote area around Indonesian Country. The problem of Polytechnic of Health of Yogyakarta in this situation was how to increase of students cognitive ability especially partnership class of remote area of Indonesia?
In many literacies showed since 2000 were many neuroscience researchers interested to develop research about pysically activity $(1)(2)(3)(4)$. Another has been known that fitnessess is needed to increase of brain function (5)(6). Except of mention above has been known that menthal resourches (ex: anxiety) as a mediator potentiality in order to correlate between sport and cognitive ability (6). All resourches has shown that was a correlation between pysically activity, sport, fitnesses and the thinking ability. Moreover their research was not much explored the specific type of the sport and had not yet explored students with limited cognitive ability as research subjects.

\section{Method of Study}

This study was used experimental by pre and post test with group control design. The number of the population was around 105 students from remote area of North of Kalimantan. Sampling number was around 79 students which were classified by cluster random sampling (39 students from "KG" school as intervention group and 40 students from " $\mathrm{K}$ " school as control group). Both of students group has the same educational bakcground namely high school as social science as basic which were staying in the same boarding house which provided by each department. Both of boarding house has $2.5 \mathrm{~km}$ distance. Except of that the study domain of two student groups taking nursing as their studying. Two schools have been choosen because they have the same number of students from remote area.

Research intervention was aerobic gymnastic. Each aerobic conducted around 40 minutes including warming up and 


\section{International Journal of Science and Research (IJSR) \\ ISSN (Online): 2319-7064}

Index Copernicus Value (2013): 6.14 | Impact Factor (2015): 6.391

cooling down. Aerobic conducted every morning, five times a week for 4 weeks only between middle test and final test schedule. Aerobic gymnastic was led by instructor with medium music sound. Joining students in aerobic gymnastic was monitored by researchers using attendance list.

Variable of this study was fitnes, anxiety and academic grade of students. Renaud M (2010) explained that fitness was fit condition which was measure with grade VO2 max (7). Measuring noted by written their time when they were walking fast in 1,6 km distance by stopwatch. Walking time has been reached in order to transfer to the size of VO2 maximum (8)(7). Anxiety was psychology reponse that was experienced by respondents in learning process (9), which was measured by using quisioner State Trait Anxiety Inventory (STAI) (10), self reported. Fitnesses and anxiety was measured two times which were pre test and post test. Academic grade was result grade earned from middle test as pretest and final test as posttest which have earned from academic administration of both departments (secondary data). The subject which has been chosen was fundamental of nursing because that subjects has been taught of both group respondents with the same unit (3 Units) and teacher.

There were three variables which predicted effectively of the study intervention namely age (Tomporowski, 2008), sex, and educational background. Age and sex have been collected using quisioner or self reported. Parental educational bakcground was a time which were used by their parents to finish of their formal study until reaching certificate of diploma. For example graduated from elementary school $(\mathrm{SD})=6$ years in , Junior High School $(\mathrm{SLTP})=9$ years, Senior High School $(\mathrm{SMU})=12$ years, Diploma III/Akademi $=15$ years, Bachelor degree $=16$ years, Master degree $=18$ years, and Doctoral Degree $=22$ years. Three variables were measured by form/quesioner, self reported.

Fitnesses increasing data (pre-post test), decreasing anxiety (pre-posttest) and increasing academic result (grade middle test-grade final test) were analized by using Mancova (Multivariate of Co-variance) repeated adjustmen where used by preveiously researchers, level of significance 0,05 by covariance control, after normality testing by using Kolmogorov-Smirnov. This research has been recomended by Medicine Ethic Committe of Muhammadiyah University of Yogyakarta.

\section{Result}

\section{Characteristic Respondents}

Majority of the respondents were male students, 20 years old, lenght of parental educational background (parents) between
9-10 years or the same level with junior high school (SLTP). This was shown in the table 1.

Table 1: Characteristic respondents based on intervention group and control group.

\begin{tabular}{|c|c|c|c|c|}
\hline \multirow[t]{2}{*}{ Group } & \multirow{2}{*}{$\begin{array}{c}\text { Age } \\
(\mathrm{M} / \mathrm{F})\end{array}$} & \multicolumn{3}{|c|}{ Mean $\pm \mathrm{SD}$} \\
\hline & & Age & $\begin{array}{c}\text { Father } \\
\text { education } \\
\text { score }\end{array}$ & $\begin{array}{c}\text { Mother } \\
\text { education } \\
\text { score }\end{array}$ \\
\hline $\begin{array}{c}\text { Intervention } \\
\text { Group }(n=39)\end{array}$ & $29 ; 10$ & $19,79 \pm 1,735$ & $9,33 \pm 3,716$ & $9,56 \pm 3,589$ \\
\hline $\begin{array}{c}\text { Control Group } \\
(n=40)\end{array}$ & $26 ; 14$ & $19,82 \pm 1,517$ & $9,80 \pm 3,196$ & $8,15 \pm 3,317$ \\
\hline
\end{tabular}

\section{Aerobic Gymnastic}

Aerobic gymnastic conducted by 39 samples as intervention group every morning at 05.30 based on west indonesian time. Aerobic gymnastic conducted together and led by one instructur in order to get the same movements together with medium music sound. Aerobic conducted in front of Polytechnic of Health of Yogyakarta with duration 40 minutes including warming up and cooling down. Aerobic gymnastic conducted 5 days a week in 4 weeks. Students controlled their joining by using attendance list. All intervention students joining at the gymnastic at the first until the last.

\section{Fitnes, Anxiety, and Academic Grades}

Fitnesses condition to intervention group shown grade increasing around 3,42 or $14,76 \%$. It was opposite with the group control happened decreasing significantly. The average grade decreased 1,25 or $3,94 \%$. For the group intervention was decreased anxiety after intervention around 8,38 or $21,20 \%$, while in group control was decreased 3,67 or $9,72 \%$. But decreasing anxiety or group intervention more than group control. Both groups was happening academic grade increased after being intervention moreover goup intervention was more than group control. The average grade increased of group intervention was 26,61 or $60,28 \%$ and group control was only 3,26 or $9,57 \%$. It can be seen at tabel 2

Mancova test was conducted when the date distributed normally ( $p$ value $=0,05$ ). The result of kolmogorov-smirnov test significantly at group control such us: data increment in fitness $\mathrm{Pv}=0.056$ and $\mathrm{pv}=0.699$; data increment in anxiety $\mathrm{Pv}=0.794$ and 0.894; data increment in academic grade $\mathrm{Pv}=0.499$ and $\mathrm{Pv}=0.958$. Mancova analysis was conducted with 0.05 level of significance. The result shown that there was significantly effective of aerobic gymnastic to dependent variables such us fitness, decresed of anxiety, and increased of academic grade with $\mathrm{Pv}=0.0001$ after being covariance controlled factor namely age, sex, and parental education. There were covarinces affected to fitness and academic grade but no one affected to the anxiety. 


\section{International Journal of Science and Research (IJSR) \\ ISSN (Online): 2319-7064}

Index Copernicus Value (2013): 6.14 | Impact Factor (2015): 6.391

Table 2: Data of fitness, Anxiety, and Grade academic

\begin{tabular}{|c|c|c|c|c|c|c|}
\hline \multirow[t]{2}{*}{ Variable } & \multirow[t]{2}{*}{ Group } & \multirow{2}{*}{$\begin{array}{c}\text { Pretest } \\
\text { Mean } \pm \text { SD }\end{array}$} & \multirow{2}{*}{$\begin{array}{c}\text { Posttest } \\
\text { Mean } \pm \text { SD }\end{array}$} & \multirow{2}{*}{\begin{tabular}{|c|} 
Increment/increased \\
Mean \pm SD
\end{tabular}} & \multicolumn{2}{|c|}{$\mathrm{P}_{\text {value }}{ }^{\mathrm{a}}$} \\
\hline & & & & & $\%$ & \\
\hline \multirow{2}{*}{$\begin{array}{c}\text { Fitness } \\
\left(\mathrm{VO}_{2} \text { Maks } \mathrm{ml} / \mathrm{Kg} / \text { minutes }\right.\end{array}$} & Intervention $(\mathrm{n}=39)$ & $23,10 \pm 1,81$ & $26,51 \pm 2,39$ & $3,41 \pm 2,33$ & 14,76 & \multirow[t]{2}{*}{$0,013^{*}$} \\
\hline & Control $(n=40)$ & $31,7 \pm 6,753$ & $30,45 \pm 6,51$ & $-1,25 \pm 9,80$ & $-3,94$ & \\
\hline \multirow[t]{2}{*}{ Anxiety } & Intervention $(\mathrm{n}=39)$ & $39,53 \pm 5,85$ & $31,15 \pm 5,58$ & $8,38 \pm 6,53$ & 21,20 & \multirow[b]{2}{*}{$0,001^{*}$} \\
\hline & Control $(n=40)$ & $37,80 \pm 6,28$ & $34,12 \pm 8,21$ & $3,67 \pm 4,23$ & 9,72 & \\
\hline \multirow[t]{2}{*}{ Academic Grade } & Intervention $(\mathrm{n}=39)$ & $44,15 \pm 11,71$ & $70,77 \pm 4,72$ & $26,61 \pm 9,68$ & 60,28 & \multirow[b]{2}{*}{$0,0001^{*}$} \\
\hline & Control $(n=40)$ & $34,12 \pm 6,21$ & $37,39 \pm 9,30$ & $3,26 \pm 11,99$ & 9,57 & \\
\hline
\end{tabular}

a Mancova Test

${ }^{*}<0,05$ or Significance

Table 3: Test of Between Subject Effect Co-Variances to Dependen Variables

\begin{tabular}{|c|c|c|c|c|}
\hline Source & $\begin{array}{l}\text { Dependen } \\
\text { Variables }\end{array}$ & $\begin{array}{l}\text { Mean } \\
\text { Square }\end{array}$ & $F$ & $P$ value $^{a}$ \\
\hline \multirow[t]{3}{*}{ Sex } & Fitnesses & 562,439 & 12,623 & $0,001^{*}$ \\
\hline & Anxiety & 14,492 & 0,465 & 0,497 \\
\hline & Academic Grade & 423,314 & 4,079 & $0,047^{*}$ \\
\hline \multirow[t]{3}{*}{ Age } & Fitnesses & 31,579 & 0,709 & 0,403 \\
\hline & Anxiety & 0,297 & 0,010 & 0,922 \\
\hline & Academic Grade & 19,844 & 0,191 & 0,663 \\
\hline \multirow{3}{*}{$\begin{array}{l}\text { Father } \\
\text { education }\end{array}$} & Fitnesses & 1,865 & 0,042 & 0,838 \\
\hline & Anxiety & 0,185 & 0,006 & 0,939 \\
\hline & Academic Grade & 336,754 & 3,245 & 0,076 \\
\hline \multirow{3}{*}{$\begin{array}{l}\text { Mother } \\
\text { education }\end{array}$} & Fitnesses & 17,040 & 0,382 & 0,538 \\
\hline & Anxiety & 11,596 & 0,372 & 0,544 \\
\hline & Academic Grade & 463,721 & 4,469 & $0,038^{*}$ \\
\hline \multirow{3}{*}{$\begin{array}{l}\text { Interventio } \\
\mathrm{n} \text { Control }\end{array}$} & Fitnesses & 287,217 & 6,446 & $0,013^{*}$ \\
\hline & Anxiety & 398,920 & 12,807 & $0,001^{*}$ \\
\hline & Academic Grade & 12152,068 & 117,110 & $0,000^{*}$ \\
\hline
\end{tabular}

\section{Discussion}

\section{Aerobic Gymnastic and Fitnessess}

There were significance effects of joining students with aerobic gymnastic to the fitnessess. Increased of fitnessess caused of lung vital capacity, cardiorespiratory endurance, effects on strength and muscle endurance including abdominal muscle (12), and increasing of cardiorespiratory function (13). Fitnesses was a part of heart function, blood function, and haemoglobin $(\mathrm{Hb})$. Changing of $\mathrm{Hb}$ as a catcher of oxygen in the blood and changes in blood volume propulsive heart work, effectively significance of VO2 maximum and airway resistance (aerobic performance).

According to Glendhil, N (1999), there was the role of $\mathrm{Hb}$ in increasing VO2 max (14). One of the Hb levels in blood donating was the intake of nutrition. On the respondents in both groups (treatment and control), they both live in a student dormitory management of eat was organised by one management. Thus, nutrient intake on the respondents in the two groups wererelatively the same and have no effect on fitness differences that existed. In other words an increase in fitness on the respondent's treatment group was a result of their participation in the activities of the aerobic gymnastics.

Respondents to this study was the student average age of 20 years, including the age of adolescence. The research was in line with the results of previous research, that there was the influence of physical fitness activities against children (2), adolescents (4) and old age (58-85) (13). The difference between the results of this research with some previous research was a form of physical activity on the research already specific, namely aerobic gymnastic. whereas previous studies still were common, namely sports. As for co-variance that come into effect on the significance of this fitness was gender.

\section{Aerobic gymnastic and anxiety}

The results showed that the sport of gymnastics can be significantly lower the anxiety of teen age students. Decline of anxiety caused by the increased blood flow to the brain. For the next will happen an increase hormone norepinephrine and endorphins that will reduce stress, anxiety and improving mood (15). Exercise and yoga also affects the emotions in adults (7). Mechanism of sports against the anxiety of change can involve a complex neuro-chemical and modification function of brain areas of the limbic system (12). The results of this study were in line with several previous research results that show exercise improves mental resources by reducing depression (16), reduces anxiety and chronic stress and self-efficacy (17).

There was no co-variance under the significance value of anxiety. These results were inconsistent with the results of research in Pakistan. There was involvement of the gender test result anxiety on medical students. Women were significantly higher anxiety test results compared with men. The medical profession were perceived society as a profession more open both to men and women. Whereas the existing social role in society more Pakistan lies in the male patriarchal system. Thus arises the emotions of vulnerability and threat on the women, even though they have been given the same opportunity (18). Other terms of her health with students became the subject of this study, there is the same social roles between men and women in society. The public perception towards the profession of nurse (nurses and dental nurse or public), was women's work. The data show that nursing students were dominated by women. The existence of this social role opportunities encourage women more confident and prepared to overcome feelings of insecurity.

\section{Aerobic Gymnastic and Academic Grade}

There was the influence of academic values to increased gymnastics. Academic value was one indicator of students ' intellectuality. The increase in the value of the academic caused due to increased blood flow to the dorsolateral prefrontal cortex. This condition causes physical activity such as gymnastics can exhibit the changes specific to a certain part of the brain (4) (19) which will increase hormone

\section{Volume 5 Issue 7, July 2016 www.ijsr.net}




\section{International Journal of Science and Research (IJSR) \\ ISSN (Online): 2319-7064}

Index Copernicus Value (2013): 6.14 | Impact Factor (2015): 6.391

norepinephrine and endorphins. A second growth hormone will affects the growth of the brain, namely the growth of new nerve cell and cell brain synapsis, both of which constitute based of learning (15).

The increase of average rating on the Group's intervention of 60.297 percent. This academic value remains the range obtained earlier researchers of 55 to 68 percent (20). There were 2 (two) co-variances that were instrumental increasing the academic grade. The first covarian was gender. These results were in accordance with the results of the research on medical students in Pakistan and at the National University of Ireland Galway (NUIG). Studies in Pakistan showed that the achievements of the men significantly higher compared with women who were measured using Grade Point Average Score (18). Likewise the NUIG research produces information that becomes meaningful predictor of gender in reaching graduation with honors at both the subject-based curriculum and system-based curriculum (21).

As for the second covarian was the educational level of the mother. This showed how important the role of the mother in her son's accomplishments. The more parents involved early in the educational process of the child, the more powerful effect on a child's achievement. If parents get involved in education then the students will gain an increase in test scores and increased motivation. Parents of children of high achievement will put high standards on the educational activities of his children than the parents of the kids that his low (22). However, the link between maternal education in the enhancement of the value of the Cubs was far from strong. Research on young mothers produce information that young mothers with low education will be able to realize a better value than the Cubs if they equip it with additional education. But the education of mothers was not able to predict the increase in achievement of his son (23).

\section{Research Limitation}

Limitations of this research was not developed specifically for tests measure academic value and time-limited intervention because the respondent must follow the final exams of the Semester specified in the academic calendar

\section{Summary}

There was the influence of aerobic gymnastics to increased fitness, decrease anxiety and an increase academic grade of students ' academic origin of remote areas. The increase in the average fitness of $14,76 \%$, a decrease of anxiety $21,21 \%$; academic value and increased on average by $60,28 \%$. The results of this research can be utilized by educational institution which hosts educational classes in cooperation with remote areas, to increase the value of academic students, in addition to improve fitness and reduce their anxiety.

\section{References}

[1] Sibley, BA; Etnoier J. The relationship between physical activity and cognition in children: a meta-analysis. Pediatr Exerc Sci. 2003;15:243-56.
[2] Ploughman M. Exercise is brain food: the effects of physical activity on cognition function. Dev Neurorehabil. 2008;11:236-40.

[3] Hartman,T; Zahner,L; Puhse, U; Puder, JJ; Kriemler S. Effects of school-based physical activity program on physical and psychosocial quality of life in elementary school children: a cluster randomized trial. Pediatr Exerc Sci. 2010;22:511-22.

[4] Buchan D et al. Physical fitness in childhood and adolescence: a powerful maker of health. Int Obes. 2011;32:1-11.

[5] Bherer, L; Erickson, KI; Liu-Ambrose T. A review of the effects of physichal activity and axercise on cognitive and brain functions in older adults. Journal of Aging Research. Hindawi Publishing Corporation; 2013. p. 8 pages.

[6] Spirduso, W; Poon, L; Chodzo-Zajko W. Using resources reserves in an exercise-cognition model in W.Spirduso IP and W. Chodzo-Zajko, Eds Eds Exercise and Its Mediating Effects on Cognition. In: Spirduso IC$Z$, editor. Exercise and mediating effects on cognition. Human Kinetics Campaign III USA; 2008. p. 3-11.

[7] Renaud,M; Maquestiaux,F; Joncas, S; Kergoat, MJ; Bherrer L. The effects of three months of aerobic training on response preparation in older adults. Front Aging Neurosci. 2010;2(148).

[8] Dirjen Bina Gizi dan Kesehatan Ibu dan Anak Kemenkes RI. Leaflet Kartu Menuju Sehat. Yogyakarta: Dinas Kesehatan D.I.Y; 2011;

[9] Ozen, NS; Ercan I. Anxiety prevalence and affecting factors among university students. Asia Pasific J Public Heal. 2010;22(1):127-8.

[10] Spielberger, CD; Gorsuch R. Manual for state-trait anxiety inventory. Palo Alto CA Colsulting Psychologists Press; 1970.

[11] Tomporowski, PD; Davis, CL; Miller, PH; Naglieri J. Exercise and children's intelligence, cognitive and academic achievement. Educ Psychol Rev. 2008;20(2):111-31.

[12] Telles et al. Effect of yoga or physical, cognitive and emotional measures in children: a randomized controlled trial. [Internet]. Child and Adolescenty and Mental Health Psychiatr. 2013. Available from: hhtp://creativecommons.org/licenses/by/2.0

[13] Pennington, R; and Hanna S. The accute effects of exercise on cognitive performance of older adult. J Arkansas Acad Sci. 2013;67:109-14.

[14] Glendhil, N; Warburton, D; Jmnik. Haemoglobin, blood volume, cardiac function and aerobic power. Can J Appl Physiol. 1999;24(1):54-65.

[15] Paton G. Daily exercise significantly improve pupils test score [Internet]. 2012 [cited 2014 Apr 21]. Available from:

http://www.telegraph.co.uk/education/educationnews/91 33534/Daily-exercise-significantly-improves-pupils-tes

[16] Bartholomew, J; Ciccolo J. Exercise depression and cognition. In: Spirduso, W; Chodzo-Zajko W, editor. Exercise and its mediating effects on cognition human kinetics. Champaign III USA; 2008. p. 33-46.

[17] MCAuley, E; Elavsky S. Self eficacy, physical activity and cognitive function. In: Spirduso, IP; Chodzo-Zaijko $\mathrm{W}$, editor. Exercise and its mediating effects on

\section{Volume 5 Issue 7, July 2016} www.ijsr.net 


\section{International Journal of Science and Research (IJSR) \\ ISSN (Online): 2319-7064 \\ Index Copernicus Value (2013): 6.14 | Impact Factor (2015): 6.391}

cognition human kinetics. Human Kinetics Campaign III USA; 2008. p. 69-84.

[18] Farogi, YR; Ghani, R; Spielberger C. Gender differences in test anxiety and academic performance of medical student. Int J Psychol Behav Sci. 2012;2(2):38-43.

[19] Cohen D et al. Cerebral blood flow effects of yoga training: preliminary evaluation of 4 cases. J Altern Complement Med. 15:9-14.

[20]Karen M. Brain boost: sport and physical activity enhance children's learning. [Internet]. 2010 [cited 2014 Apr 22]. Available from: http://www.westportnort.cshool.nz/files/253f39edfcbca3 68/file set file/000/0091/brer.pdfain boost email

[21] McVeigh, TP; Dunne F. Gender differences in undergraduate medicine in Galway: a tale of two curricula. Irish J Madical Sci. 2014;183(1):103-10.

[22] Michigan Departemen of Education. What research says about parent involvement in children's education in ralation to academic achievement. Michigan Department of Education; 2001.

[23] Magnuson K. Maternal education and children's academic achievement during middle childhood. Artic Sel Dev Psychol. 2007;43(1):1497-512.

Volume 5 Issue 7, July 2016 www.ijsr.net 